ference of the disease to other persons, animals or inanimate objects; (2) animal, plant or mineral remedies; (3) religious influences, including the invocation of special saints; (4) the healing power attributed to water in the form of wells, springs, fountains and streams; (5) the mystical power of odd numbers ; (6) repellent and disgusting remedies, including coprotherapy, for the purpose of drawing out the evil spirit supposed to be the cause of the disease ; (7) miscellaneous causes, such as the doctrine of signatures, constriction by rings, charms connected with death or the grave, etc. The diseases and symptoms for which the largest number of folk-lore remedies and preventive methods have been applied are whooping cough, 'ague', including not only malaria, but also as its etymology indicates, any acute fever, epilepsy and convulsions of any kind, rheumatism, consumption, eye diseases, skin diseases, especially warts, cattle diseases, headache, toothache, jaundice, hæmorrhages of any kind, and bites of snakes and scorpions. After giving numerous examples of folk-lore medicine in whooping cough, epilepsy, rheumatism and jaundice, Dr. Rolleston concluded by saying that, though many folk-lore remedies have become obsolete, some are still practised, not only by the inhabitants of remote country districts, but also by educated persons in large cities.

\section{The New Deal in Education in the United States}

THE Federal Government of the United States seems likely, in future, to play an increasingly im. portant part in the education services of the States. A summary has recently been published ("The Federal Government and Education". Washington, D.C. : Superintendent of Documents. Price 10 cents) of certain findings and proposals of the President's Advisory Committee on Education relating to present conditions with special emphasis on inequalities of educational opportunity, the national interest in education and proposals for federal grants amounting in 1939-40 to 72 million dollars and increasing gradually to 202 millions in 1944-45. The Committee found that "glaring inequalities characterize educational opportunities throughout the nation" and it is argued that federal aid is the only way of adequately remedying this evil. It is pointed out that while the abilities of the States and local communities to provide education have always been unequal, recent changes in social and economic conditions have magnified this inequality and at the same time education has become increasingly important. Fundamentally the inequality is largely due to drainage of wealth, through migration and modern methods of organization of manufacture, commerce and finance, from all parts of the country into the towns and cities and particularly the great metropolitan areas. Hence such glaring contrasts as that between a farm population in the south-eastern States responsible for $4 \frac{1}{4}$ million children, with only 2 per cent of the national income, and a non-farm population in the north-east with $8 \frac{1}{2}$ million children, and 42 per cent of the national income- -21 times as much income from which to educate only twice as many children.

\section{The Josiah Macy, Jr. Foundation}

IN a six-year review of the activities of the Josiah Macy, Jr. Foundation, New York, 1930-1936, Dr. Ludwig Kast, president of the Foundation, reports that up to December 31, 1936, the Foundation made 324 grants, amounting to 806,681 dollars, to thirtyfour different universities and twenty-seven other agencies for research in the United States, Belgium, Czechoslovakia, France, Germany, Hungary, Netherlands and the U.S.S.R. Special reference is made in the report to the interest of the Foundation in psychosomatic problems, including a survey of the relation of emotion to disease, to its support of investigations upon growth, development, maturation and ageing, the bearing of which upon the changing age distribution of population in the United States and the problems arising from that trend are stressed, as well as in social research concerming health and sickness and medical education. The Foundation in 1933 published the results of a review of the available data and immediate problems in human arterioselerosis in a volume entitled "Arteriosclerosis : a Survey of the Problem", and the report emphasizes that, in view of the tendency for the age distribution of population to change towards a predominantly older group with a smaller population less than twenty years of age, the problems associated with the ageing of individual men and women are not merely medical problems but also require study by workers in other branches of science. such as economics and sociology. A chronological list of grants is included in the report.

\section{Steam Boilers for Electric Power Stations}

CONSIDERABLE progress has recently been made in developing the type of boiler used in electric power stations. It is now generally recognized that considerable economies can be effected by the use of larger steam-generating units, higher steam pressures and higher temperatures. The average capacity of boilers now being installed in power stations has risen to nearly $200,000 \mathrm{lb}$. of steam per hour. These work in conjunction with alternating current generators giving 30,000-50,000 kilowatts. In the Electrical Times of November 24 a description is given by $\mathrm{Mr}$. V. Walker of a number of the latest types of boilers recently installed. Attention is also directed to the alterations made necessary when pulverized fuel is used. Messrs. Babcock and Wilcox have developed some of their boilers so as to take advantage of the economies inherent in the use of high rates of heat release per square foot of furnace now obtainable. They have designed a boiler for the Brighton Corporation so as to have a normal evaporation of $175,000 \mathrm{lb}$. per hour at $675 \mathrm{lb}$. pressure per square inch and $875^{\circ} \mathbf{F}$. To overcome the difficulties of natural circulation, forced circulation has been developed. Two other types of boiler, the La Monte and the Loeffler, are also being installed in Great Britain.

\section{Recent Additions to the British Museum (Bloomsbury)}

AMONG the additions of archæological interest reported at the meeting of the trustees of the British Museum (Bloomsbury) on January 14, was a 
collection of bronze age pottery from Cyprus, which had been excavated by Mr. J. R. Stewart from two graves at Vounous in that island. The pottery belongs to the periods Early Cypriote Ia and $\mathrm{I} b$, dating from about 2800-2700 B.C., and Early Cypriote II $a$, which is placed at approximately two hundred years later. Lieut.-Colonel H. H. R. Deane has presented a collection of examples of Buddhist art, consisting of twenty pieces, mostly small stone figures, belonging to the Gandhara School, dating from the second to fourth centuries A.D. These were collected in the North-West Frontier Province by the late Lieut.-Colonel H. A. Deane.

\section{Recent Appointments in the Colonial Service}

THE following appointments in the Colonial Service have recently been made: Colonial Forest Service, W. B. Collins, Gold Coast ; D. F. Davidson, Cyprus ; M. T. Horwood, Gold Coast ; F. C. Hummel, Uganda; T. W. Hussey, Nigeria; D. M. M. Kellas, Gold Coast ; D. A. Lane, Gold Coast ; H. M. MaughanBrown, Sierra Leone; W. A. Miller, Gold Coast ; J. M. Ramsay, Gold Coast ; G. G. K. Setton, Fiji ; P. G. Shillitoe, Tanganyika. Colonial Agricultural Service, C. Harvey (agricultural officer, Tanganyika Territory), senior agrieultural officer, Fiji; F. L. Squibbs (director of agriculture, Seychelles), agricultural officer, Gold Coast. Colonial Geological Survey Service, J. B. Alexander (geologist, Nyasaland), geologist, Federated Malay States ; H. Service (geologist, Gold Coast), geologist, Federated Malay States. Colonial Veterinary Service, W. G. Beaton (senior veterinary officer), deputy director of veterinary services, Nigeria; H. J. Lowe (senior veterinary officer), director of veterinary services, Tanganyika Territory; Captain W. L. S. Mackintosh (veterinary officer), senior veterinary officer, Uganda ; R. J. Simmons (senior veterinary officer), director of veterinary services, Uganda. Other Branches, W. R. Chanmugam (assistant Government analyst), deputy Government analyst, Ceylon; Miss R. M. Henderson, bacteriologist, Veterinary Department, Kenya; G. P. C. Lewis, inspector of plants and produce, Gold Coast.

\section{Announcements}

M. L. Cayeux, member of the Paris Academy of Sciences and honorary professor of geology at the Collège de France, has been awarded the Paul Fourmarier Prize and gold medal by the Royal Academy of Belgium.

THE Council of the Institution of Naval Architects has awarded the Gold Medal of the Institution for the year 1938 to A. P. Cole, for his paper "Destroyer Turning Circles", and the Premium to Dr. F. H. Todd and J. Weedon for their joint paper "Further Resistance and Propeller Experiments with Models of Coasters". The Wakeham Prize for 1938 has been awarded to I. C. Bridge for his paper "Structural Stress in an Oil Tanker Under Service Conditions". These awards will be presented at the annual general meeting on March 29 at the Royal Society of Arts, John Street, London, W.C.2.
The Gold Medal of the Intermational Faculty of Sciences, which is awarded annually in recognition of outstanding contributions to scientific progress, has been awarded for 1938 to Mr. J. J. Denton, secretary of the Television Society, and vice-president of the Institution of Electronics. The award is in recognition of nearly fifty years' continuous devotion to scientific and technical education.

THE herbarium and library of the Botanical Museum of the Academy of Sciences of the U.S.S.R. are being transferred from Leningrad to Moscow. It is not expected that the new museum in Moscow will be ready for another five years. The Botanical Gardens in Leningrad will be retained.

WE have received a new schedule of fees for tests on volumetric glassware at the National Physical Laboratory which came into operation on December 1, certain modifications in the method of charging being introduced. The tests available and the methods used are described in a pamphlet entitled "Tests on Volumetric Glassware" which, together with the schedule of fees, may be obtained on application to the Director, National Physical Laboratory, Teddington, Middlesex.

The Educational Advisory Board of the British Social Hygiene Council is holding a Summer School, dealing with "Biology in Human Life", probably at Cambridge, on July 28-August 4. The School will include courses on social biology, and the place of the teacher with regard to the teaching of sex, and lectures by experts on recent developments in the biological field. The course is intended for all teachers, particularly those in senior and secondary schools, who are interested in biological problems as they affect human life and society. Further particulars can be obtained from the Education Officer, British Social Hygiene Council, Tavistock House South, Tavistock Square, London, W.C.1.

The fourth biennial Child Guidance Conference will be held at the British Medical Association House, Tavistock Square, W.C.1, on January 27-28, when the subjects for discussion will include : treatment of parents, juvenile delinquency, personality deviations and diagnosis of psychoses, the scope of the educational psychologist working in the schools and substitute homes. A session for administrative regulations will also be devoted to the consideration of the findings of the Feversham report on the voluntary mental health services as they affect the policy and administration of the child guidance movement. Further information can be obtained from the Secretary, Child Guidance Council, Woburn House, Upper Woburn Place, W.C.1.

ErRatum.-In Nature of December 3, 1938, p. 997, col. 2, letter by Prof. A. Schönberg, last reaction :

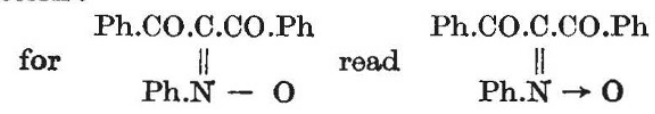

